\title{
Expression and localization of Indian hedgehog (Ihh) and parathyroid hormone related protein (PTHrP) in the human growth plate during pubertal development
}

\author{
J M Kindblom, O Nilsson ${ }^{1}$, T Hurme $^{2}$, C Ohlsson and \\ L Sävendahl' \\ Research Center for Endocrinology and Metabolism, Department of Internal Medicine, The Sahlgrenska Academy at Gothenburg University, \\ SE-413 45 Gothenburg, Sweden \\ ${ }^{1}$ Pediatric Endocrinology Unit, Department of Woman and Child Health, Karolinska Institutet, SE-171 76 Stockholm, Sweden \\ ${ }^{2}$ Department of Pediatric Surgery, Turku University Hospital, FIN-205 20 Turku, Finland \\ (Requests for offprints should be addressed to L Sävendahl; Email: lars.savendahl@kbh.ki.se) \\ (J M Kindblom and O Nilsson contributed equally to this work)
}

\begin{abstract}
Indian Hedgehog (Ihh) has been reported to control the rate of cartilage differentiation during skeletal morphogenesis in rodents through a negative feedback loop involving parathyroid hormone related protein $(\mathrm{PTHrP})$. The role of Ihh and PTHrP in the regulation of human epiphyseal chondrocytes is unknown. The aim of the current study was to examine the expression and localization of Ihh and PTHrP in the human growth plate at various pubertal stages. Growth plate biopsies were obtained from patients subjected to epiphyseal surgery and the expression of Ihh
\end{abstract}

and PTHrP was detected by immunohistochemistry. We show that Ihh and PTHrP are expressed mainly in early hypertrophic chondrocytes in the human growth plate. The levels of expression of Ihh and PTHrP are higher in early stages of puberty than later. Our results suggest that Ihh and PTHrP are present in the human growth plate and that Ihh and PTHrP may be involved in the regulation of pubertal growth in humans.

Journal of Endocrinology (2002) 174, R1-R6

\section{Introduction}

Longitudinal bone growth takes place in the growth plate through a process called endochondral bone formation. In this process, chondrocytes in the resting zone are recruited to start active proliferation and then undergo differentiation, which is followed by apoptosis and eventually mineralization. The balance between proliferation and differentiation is a crucial regulatory step controlled by various growth factors acting in endocrine as well as paracrine/autocrine ways.

Parathyroid hormone related protein (PTHrP) has been shown to be essential as a limiting factor in chondrocyte differentiation in the fetal murine growth plate (Lanske et al. 1996, Vortkamp et al. 1996). The secreted protein Indian hedgehog (Ihh), expressed in murine hypertrophic chondrocytes (Bitgood and McMahon 1995), is an important regulator of PTHrP (Karp et al. 2000, St-Jacques B et al. 1999, Vortkamp et al. 1996). A negative feedback loop is thereby formed. In fetal bone, this Ihh/PTHrP loop has been suggested to include Ihh-stimulation of the periarticular cartilage to express $\mathrm{PTHrP}$, which then acts on the prehypertrophic chondrocytes to inhibit further differentiation (Vortkamp et al. 1996).

Elegant knock-out experiments have confirmed that PTHrP signals directly to the PTH/PTHrP receptor on proliferating chondrocytes to slow their differentiation (Chung et al. 1998). In addition, Ihh has also been shown to directly act on the chondrocytes themselves at particular stages of embryonal development (St-Jacques B et al. 1999, Vortkamp et al. 1998). In the postembryonic growth plate, a local negative feedback loop has been proposed in which postproliferative chondrocytes secrete Ihh, which increases secretion of PTHrP to slow hypertrophy and thereby slow production of cells that secrete Ihh (Farquharson et al. 2001). Recently, PTHrP was also shown to directly inhibit Ihh expression in rabbit rib chondrocytes, which further supports the presence of a functional Ihh/PTHrP negative feedback loop (Yoshida et al. 2001). Studies in chick, rat, and rabbit postembryonic growth plates 
Table 1 Physical findings in the 10 patients and expression of Ihh and PTHrP in each of the 10 subjects. Bone ages were determined according to the Gruelich-Pyle standard. The percentage of positively stained cells was counted using an image analysis system. By thresholding against unstained cells, the system automatically detected stained cells

\begin{tabular}{|c|c|c|c|c|c|c|c|}
\hline & Sex & $\begin{array}{l}\text { Tanner pubertal } \\
\text { stage }\end{array}$ & $\begin{array}{l}\text { Age } \\
\text { (yr:mth) }\end{array}$ & $\begin{array}{l}\text { Bone age } \\
\text { (yr:mth) }\end{array}$ & Diagnosis & $\begin{array}{l}\text { Ihh } \\
\text { (\% pos cells) }\end{array}$ & $\begin{array}{l}\text { PTHrP } \\
\text { (\% pos cells) }\end{array}$ \\
\hline \multicolumn{8}{|c|}{ Subject } \\
\hline 1 & $\mathrm{~F}$ & $\mathrm{~B} 3 / \mathrm{PH} 4$ & $16: 2$ & $14: 1$ & Marfan syndrome & $4 \cdot 4$ & $11 \cdot 5$ \\
\hline 3 & $\mathrm{~F}$ & $\mathrm{~B} 2-3 / \mathrm{PH} 2$ & $14: 2$ & $13: 4$ & Leg length difference & $20 \cdot 0$ & $27 \cdot 6$ \\
\hline 4 & $\mathrm{~F}$ & $\mathrm{~B} 2 / \mathrm{PH} 2$ & $12: 8$ & $11: 2$ & Leg length difference & $22 \cdot 8$ & $26 \cdot 3$ \\
\hline 5 & $\mathrm{~F}$ & $\mathrm{~B} 1-2 / \mathrm{PH} 1$ & $12: 7$ & $12: 4$ & Leg length difference & $15 \cdot 5$ & $28 \cdot 2$ \\
\hline 8 & M & $\mathrm{G} 4 / \mathrm{PH} 4$ & $13: 5$ & $15: 4$ & Leg length difference & $8 \cdot 0$ & $2 \cdot 3$ \\
\hline 9 & M & $\mathrm{G} 4-5 / \mathrm{PH} 4$ & $14: 0$ & $14: 8$ & Klinefelters syndrome & $4 \cdot 5$ & $3 \cdot 1$ \\
\hline 10 & M & G3-4/PH3-4 & $15: 4$ & $13: 6$ & Leg length difference & $2 \cdot 0$ & $9 \cdot 6$ \\
\hline
\end{tabular}

indicate that PTHrP, Ihh, and their receptors are expressed by chondrocytes which suggests that the components involved in the PTHrP regulation of terminal differentiation are intrinsic to the growth plate itself (van der Eerden et al. 2000, Farquharson et al. 2001). Loss-offunction experiments in mice have recently shown that Ihh through PTHrP controls the site at which hypertrophy occurs in the epiphyseal growth plate (Chung et al. 2001).

During human pubertal development, epiphyseal chondrocytes go through a process of maturation and mineralization. We here hypothesize that changes in the expression of Ihh and PTHrP could be linked to this process of terminal chondrocyte differentiation. However, it is unknown if Ihh and/or PTHrP are expressed in the human growth plate. The aim of the current study was to examine the expression and localization of Ihh and PTHrP in the human growth plate at different pubertal stages.

\section{Materials and Methods}

\section{Patients and tissue preparation}

Biopsies from human epiphyseal growth plates were collected from four male and six female pubertal patients (Table 1). After obtained informed consent, patients were subjected to epiphyseal surgery in order to induce arrest of longitudinal bone growth as previously described (Nilsson et al. 1999). The local ethical committees at Karolinska Hospital, Stockholm, Sweden and at Turku University Hospital, Turku, Finland approved the study. All biopsies were of the same size and processed in the same way. The specimens were immediately fixed in $4 \%$ phosphate buffered saline formaldehyde $(\mathrm{pH} 7 \cdot 4)$, decalcified $(10 \%$ EDTA, 2 days), dehydrated, and then embedded in paraffin. The tissues were cut into $5 \mu \mathrm{m}$ sections and mounted on histological glass slides (Superfrost $+/+$, Menzel-Gloeser, Braunschweig, Germany).

\section{Immunohistochemistry}

Tissue sections were dewaxed, rehydrated and endogenous peroxidase was blocked. Non-specific binding was blocked with $10 \%$ horse serum for $\mathrm{PTHrP}$ and rabbit serum for Ihh. For PTHrP, sections were digested with neuraminidase (Sigma, 0.02 U/ml, $1 \mathrm{~h}$ at room temperature). Mouse monoclonal anti-PTHrP raised against amino acids 38-64 of human PTHrP (GF08, Oncogene Science, Cambridge, MA) was used at a concentration of $1 \mathrm{mg} / \mathrm{ml}$ $\left(4{ }^{\circ} \mathrm{C}\right.$ for two days). Goat polyclonal anti-Ihh raised against an amino acid sequence at the carboxy terminus of human Ihh (sc-1196, Santa-Cruz Biotechnology, USA) was used at a concentration of $5 \mathrm{mg} / \mathrm{ml}$ ( $1 \mathrm{~h}$ at room temperature). The Ihh antibody does not cross-react with other members of the Hedgehog family. Secondary antibodies were biotinylated horse anti-mouse for PTHrP (Vector, Burlingame, CA, USA) and biotinylated rabbit anti-goat for Ihh (DAKO, Carpinteria, CA, USA).

Bound primary antibodies were detected with $\mathrm{ABC}$ complex (Vector, Burlingame, CA, USA) followed by detection of peroxidase activity using Nova Red for PTHrP and diaminobenzidine for Ihh (both from Vector, Burlingame, CA, USA). The sections were then dehydrated, cleared and mounted in Mountex (Histolab, Gothenburg, Sweden). Sections of normal prostate, obtained during transurethral resection due to benign hyperplasia, were used as positive control for PTHrP (Cramer et al. 1996). Control experiments also included incubations with non-specific antibody and competition experiments with antibody preabsorbed with the corresponding peptide (Ihh and PTHrP peptides: Santa Cruz Biotechnology, USA and Oncogene Science, Cambridge, MA, respectively).

Sections from patients in different pubertal stages were placed on the same slide exposed to exactly the same solutions, which was realised through a wax-ring extending around all of the sections. 
Quantification of Ihh and PTHrP by in situ imaging

Digital images of stained samples were transferred from a DMR-X microscope (Leica, Wetzlar, Germany) into a computerized image-analysis system (Quantimet 550IW; Leica, Cambridge, UK), which allowed for the detection of 16.7 million different colors. The percentage of positive cells: 3-5 fields, depending on the size of the biopsy were assessed for positive-stained cells and for the total number of cells present. The epiphyseal bone, the resting zone, and the metaphyseal bone were excluded. The positively stained cells in the proliferative and hypertrophic zones were detected by the program and counted manually. Results are given as the percentage of positive cells of all cells. The sensitivity and specificity of the imaging system has previously been evaluated (Bjork et al. 1997).

\section{Statistics}

Linear regression analysis was performed between Tanner pubertal stages and the percentage positively stained cells for Ihh and PTHrP, respectively. R-values were calculated and the levels of significance were tested using ANOVA (Sigma Plot 5·0, SPSS Inc, Chicago, IL).

\section{Results}

\section{Detection of Ihh and PTHrP in the human growth plate}

In all ten patients, Ihh and PTHrP immunoreactivity was mainly detected in early hypertrophic chondrocytes, whereas resting and proliferative chondrocytes were negative to both of the proteins (Fig. 1). The staining was consistently confined to the cytoplasm. Patients with strong staining for Ihh also stained strongly for PTHrP (Table 1).

To confirm the sensitivity and specificity of our immunostainings, several control experiments were performed. Control experiments showed no staining when primary antibodies were exchanged for non-immune immunoglobulins, or no or very faint staining when primary antibody was preincubated with the corresponding peptide (Fig. 1e and 1f). Human prostate tissue, used as a positive control, showed positive staining for $\mathrm{PTHrP}$ in glandular epithelium (Fig. 1g).

\section{Expression levels of Ihh and PTHrP during pubertal development}

In patients in early puberty, i.e. Tanner stages B1-2/ G1-2, Ihh and PTHrP were highly expressed in early hypertrophic chondrocytes (Fig. 1a and 1b). However, in patients in late puberty, i.e. Tanner stages B4-5/G4-5, Ihh and PTHrP was consistently expressed in a lower percentage of cells (Fig. 1c and 1d). Linear regression analysis revealed a significant negative correlation between
Tanner pubertal stage (breast development for girls, genitalia development for boys) and the expression levels of Ihh and PTHrP (Fig. 2a and 2b). No significant sex difference was observed in the expression patterns of Ihh and PTHrP.

\section{Discussion}

We here show Ihh and PTHrP immunoreactivity in human epiphyseal growth plates during pubertal development. To our knowledge, this is the first demonstration of Ihh and PTHrP in the postnatal human growth plate.

Both Ihh and PTHrP were constantly expressed in early hypertrophic chondrocytes in our pubertal female and male patients. Due to difficulties in recruiting patients, none were excluded in the present study. The majority of patients were subjected to epiphyseal surgery because of constitutional tall stature and leg length difference. Therefore, the staining pattern is not suspected to be part of a specific disease pattern. All patients were in puberty and there was no sex difference in the expression patterns of Ihh and PTHrP. The levels of expression of Ihh and PTHrP were higher in early stages of puberty than later.

The here reported pattern of expression of Ihh and the decrease with advancing age are in agreement with what has been reported for rats using the same antibody which reacts with the C-terminal subunit of human Ihh (van der Eerden et al. 2000). However, van der Eerden et al. reported wider expression pattern and absence of agerelated changes using an amino terminal Ihh antibody. Notably, this antibody cross-reacts with other members of the hedgehog family.

In our pubertal patients, $\mathrm{PTHrP}$ is mainly expressed in early hypertrophic chondrocytes. The quite localized expression of $\mathrm{PTHrP}$ is in contrast with what has been reported in rats where PTHrP expression was also detected in stem cells and mature hypertrophic chondrocytes (van der Eerden et al. 2000). The differing expression patterns could be explained by a difference in the antibody's affinity for rat versus human PTHrP, technical variations or true species-specific differences in the expression pattern of PTHrP. Both we and van der Eerden used antibodies directed against the mid-portion of the human PTHrP molecule. Measuring the levels of the mid-portion is an indirect way of studying levels of the active flanking peptides. It is worth mentioning that using an antibody directed against the active N-terminal portion of PTHrP (1-14), Kartsogiannis et al. (1997) reported immunoreactivity in hypertrophic chondrocytes in secondary ossification centres in 7-day old mice, and in hypertrophic chondrocytes in the growth plate of 7-week old mice.

We did not study the expression of receptors for PTHrP and Ihh (patched) in our patients. However, both the PTHrP receptor and patched are known to be expressed in prehypertrophic and hypertrophic chondrocytes in the rat growth plate (van der Eerden et al. 2000). 
Ihh
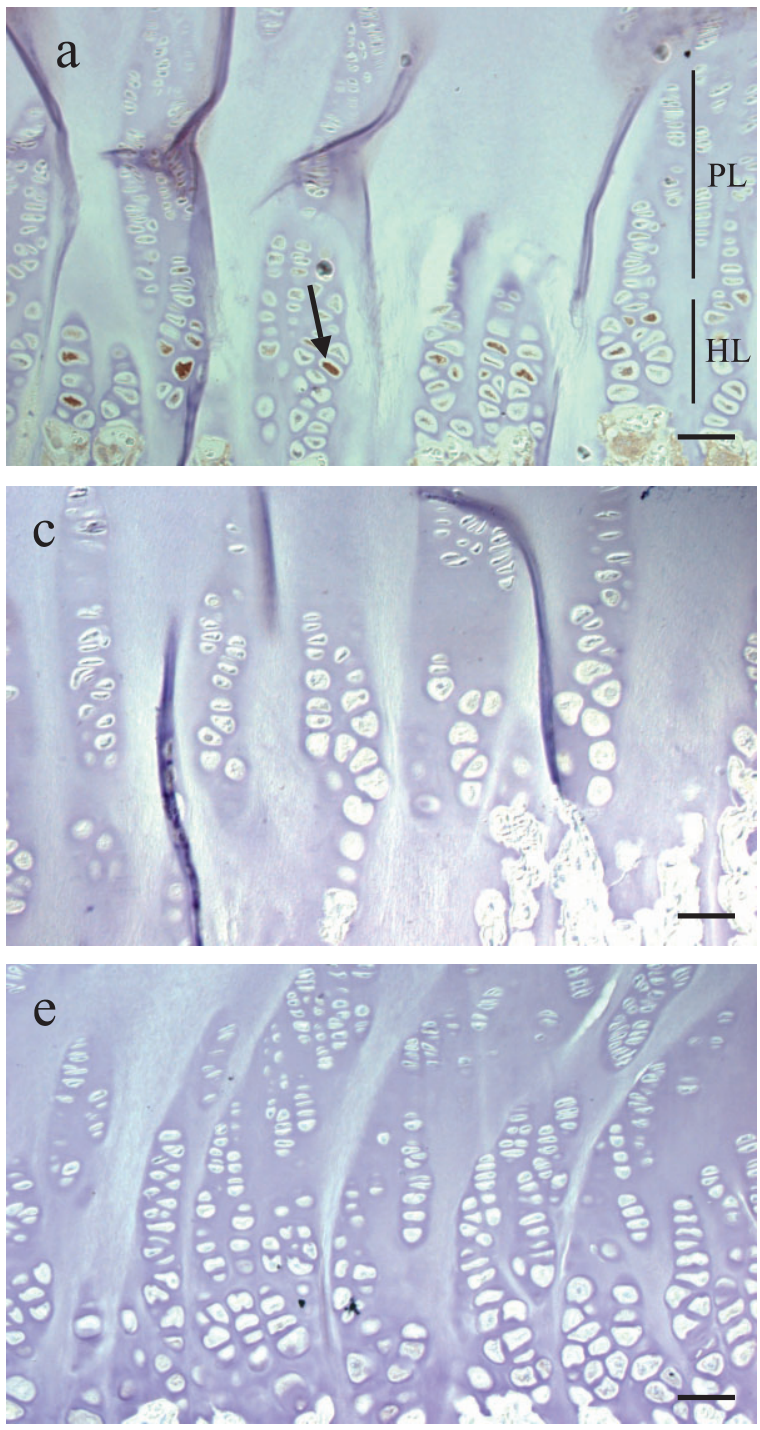

PTHrP
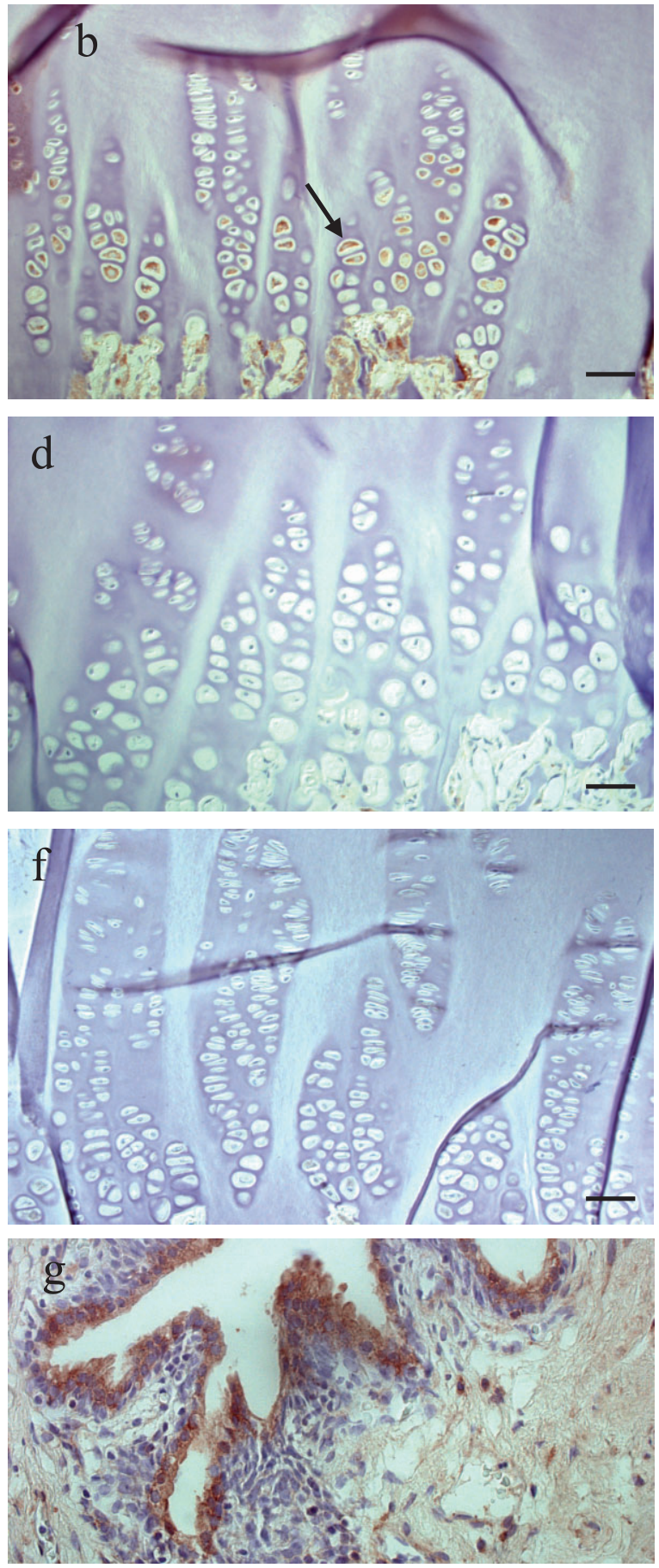

Figure $1 \mathrm{Immunohistochemistry} \mathrm{for} \mathrm{Ihh} \mathrm{and} \mathrm{PTHrP} \mathrm{in} \mathrm{growth} \mathrm{plates} \mathrm{from} \mathrm{subjects} \mathrm{at} \mathrm{different} \mathrm{pubertal} \mathrm{stages.} \mathrm{The} \mathrm{panels} \mathrm{show}$ representative stainings for Ihh in early (a) and late (c) and for PTHrP in early (b) and late (d) puberty. Panels (e) and (f) are negative controls where the primary antibodies were preincubated with Ihh peptide (e) and PTHrP peptide (f). Panel (g) shows human prostate used as positive control for PTHrP. Bar represents $50 \mu \mathrm{m}$. PL=proliferative layer and $\mathrm{HL}=$ hypertrophic layer. The arrows indicate positively stained cells. 

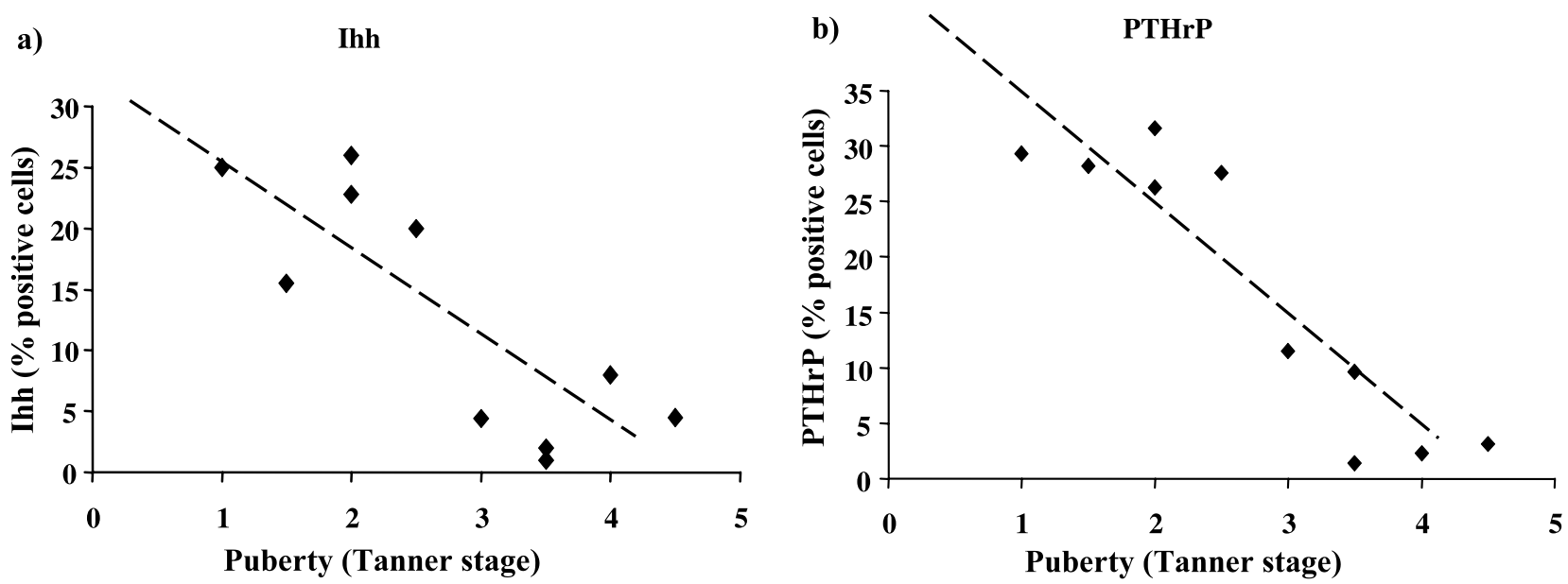

Figure 2 Correlation between Ihh (a) and PTHrP (b) and Tanner pubertal stages determined as breast (females) or genitalia (males) development. (a) $r=-0.816, P<0 \cdot 01$; (b) $r=-0.911, P<0 \cdot 001$.

Patients with loss- or gain-of-function mutations in PTHrP or its receptor show abnormal chondrocyte differentiation (Hopyan et al. 2002, Jobert et al. 1998, Schipani et al. 1997), as occurs in mice with a deletion of the gene coding for PTHrP (Chung et al. 2001, Lanske et al. 1996, Vortkamp et al. 1996). This implicates that the Ihh/ PTHrP feedback loop is a well-conserved mechanism for regulation of epiphyseal chondrocyte differentiation.

During embryonic development, the Ihh/PTHrP loop was originally suggested to involve the perichondrium (Vortkamp et al. 1996). The role of the perichondrium and periarticular region has recently been questioned since the functional components of the loop are present within the embryonic and post-embryonic growth plate (Chung et al. 1998, Farquharson et al. 2001, Kronenberg et al. 1997, van der Eerden et al. 2000, Vortkamp et al. 1998). The presence of a postnatal intrinsic Ihh/PTHrP loop is further supported by our data localising Ihh and PTHrP expression to mainly prehypertrophic/hypertrophic chondrocytes. For technical reasons, the perichondrium and periarticular tissue were not present in our biopsies and could therefore not be studied.

Our finding of negative correlations between Tanner pubertal stages/bone age and the expression of Ihh and PTHrP proteins is in agreement with the observation (van der Eerden et al. 2000) that Ihh is decreased after sexual maturation in the rat growth plate. We therefore speculate that Ihh and PTHrP are important in controlling the process of endochondral bone formation in humans as in other species and that endocrine as well as autocrine/ paracrine factors of importance for pubertal growth are involved in the regulation of Ihh and PTHrP. However further studies are needed to clarify the functional role of Ihh and PTHrP in the human growth plate.

In summary, we have detected Ihh and PTHrP immunoreactivity in the early hypertrophic layer in human growth plates. The levels of expression of Ihh and PTHrP are higher in early stages of puberty than later. The present results suggest that Ihh and PTHrP might be involved in the regulation of pubertal growth in humans.

\section{Acknowledgements}

This study was supported by the Swedish MRC (K200172X-13508-02B, K200-72X-13503-01A), the Swedish Foundation for Strategic Research, the Lundberg Foundation, the Göteborg Medical Society, the Cornell Foundation, the Sven Jerring Foundation and Förenade Liv Mutual Group Life Insurance Company, Stockholm, Sweden.

\section{References}

Bitgood MJ \& McMahon AP 1995 Hedgehog and Bmp genes are coexpressed at many diverse sites of cell- cell interaction in the mouse embryo. Developmental Biology 172 126-138.

Bjork L, Tracey KJ, Ulrich P, Bianchi M, Cohen PS, Akerlund K, Fehniger TE, Andersson U \& Andersson J 1997 Targeted suppression of cytokine production in monocytes but not in $\mathrm{T}$ lymphocytes by a tetravalent guanylhydrazone (CNI-1493). Journal of Infectious Diseases 176 1303-1312.

Chung UI, Lanske B, Lee Kaechoong, Li E \& Kronenberg H 1998 The parathyroid hormone/parathyroid hormone-related peptide receptor coordinates endochondral bone development by directly controlling chondrocyte differentiation. PNAS 95 13030-13035.

Chung UI, Schipani E, McMahon AP \& Kronenberg HM 2001 Indian hedgehog couples chondrogenesis to osteogenesis in endochondral bone development. Journal of Clinical Investigation 107 405-407.

Cramer SD, Peehl DM, Edgar MG, Wong ST, Deftos LJ \& Feldman D 1996 Parathyroid hormone-related protein (PTHrP) is an epidermal growth factor-regulated secretory product of human prostatic epithelial cells. Prostate 29 20-29. 
van der Eerden BC, Karperien M, Gevers EF, Lowik CW \& Wit JM 2000 Expression of Indian hedgehog, parathyroid hormone-related protein, and their receptors in the postnatal growth plate of the rat: evidence for a locally acting growth restraining feedback loop after birth. Journal of Bone and Mineral Research 15 1045-1055.

Farquharson C, Jefferies D, Seawright E \& Houston B 2001 Regulation of chondrocyte terminal differentiation in the postembryonic growth plate: The role of the PTHrP-Indian hedgehog axis. Endocrinology 142 4131-4140.

Hopyan S, Gokgoz N, Poon R, Gensure RC, Yu C, Cole WG, Bell RS, Juppner H, Andrulis IL, Wunder JS \& Alman BA 2002 A mutant PTH/PTHrP type I receptor in enchondromatosis. Nature Genetics 30 306-310.

Jobert AS, Zhang P, Couvineau A, Bonaventure J, Roume J Merrer ML \& Silve C 1998 Absence of functional receptors for parathyroid hormone and parathyroid hormone-related peptide in Blomstrand chondrodysplasia. Journal of Clinical Investigation 102 34-40.

Karp SJ, Schipani E, St-Jacques B, Hunzelman J, Kronenberg H \& McMahon AP 2000 Indian hedgehog coordinates endochondral bone growth and morphogenesis via parathyroid hormone related-proteindependent and -independent pathways. Development 127 543-548.

Kartsogiannis V, Moseley J, McKelvie B, Chou ST, Hards DK, Ng KW, Martin TJ \& Zhou H 1997 Temporal expression of PTHrP during endochondral bone formation in mouse and intramembranous bone formation in an in vivo rabbit model. Bone 21 385-392.

Kronenberg HM, Lee K, Lanske BMK \& Segre GV 1997 Parathyroid hormone-related protein and Indian hedgehog control the pace of cartilage differentiation. Journal of Endocrinology 154 S39-S45.

Lanske B, Karaplis AC, Lee K, Luz A, Vortkamp A, Pirro A, Karperien M, Defize LH, Ho C, Mulligan RC, Abou-Samra AB,
Juppner H, Segre GV \& Kronenberg HM 1996 PTH/PTHrP receptor in early development and Indian hedgehog-regulated bone growth. Science 273 663-666.

Nilsson LO, Boman A, Sävendahl L, Grigelioniene G, Ohlsson C, Ritzén EM \& Wroblewski J 1999 Demonstration of estrogen receptor-beta immunoreactivity in human growth plate cartilage. Journal of Clinical Endocrinology and Metabolism 84 370-373.

Schipani E, Jensen GS, Pincus J, Nissenson RA, Gardella TJ \& Jüppner H 1997 Constitutive activation of the cyclic adenosine $3^{\prime}, 5^{\prime}$-monophosphate signaling pathway by parathyroid hormone (PTH)/PTH-related peptide receptors mutated at the two loci for Jansen's metaphyseal chondrodysplasia. Molecular Endocrinology 11 851-858.

St-Jacques B, Hammerschmidt M \& McMahon AP 1999 Indian hedgehog signaling regulates proliferation and differentiation of chondrocytes and is essential for bone formation [published erratum appears in Genes \& Development 1999, 13 2617]. Genes \& Development 13 2072-2086.

Vortkamp A, Lee K, Lanske B, Segre GV, Kronenberg HM \& Tabin CJ 1996 Regulation of rate of cartilage differentiation by Indian hedgehog and PTH-related protein. Science 273 613-622.

Vortkamp A, Pathi S, Peretti GM, Caruso EM, Zaleske DJ \& Tabin CJ 1998 Recapitulation of signals regulating embryonic bone formation during postnatal growth and in fracture repair. Mechanisms of Development 71 65-76.

Yoshida E, Noshiro M, Kawamoto T, Tsutsumi S, Kuruta Y \& Kato Y 2001 Direct inhibition of Indian hedgehog expression by parathyroid hormone (PTH)/PTH-related peptide and up-regulation by retinoic acid in growth plate chondrocyte cultures. Experimental Cell Research 265 64-72. 